\title{
Relationship between antibiotic residues and occurrence of resistant bacteria in Nile tilapia (Oreochromisniloticus) cultured in cage-farm
}

Sérgio H. Monteiro, Fabiana Garcia, Kátia S. Gozi, Daiane M. Romera, Jeane G. Francisco, Graziela C. R. Moura-Andrade \& Valdemar L. Tornisielo

To cite this article: Sérgio H. Monteiro, Fabiana Garcia, Kátia S. Gozi, Daiane M. Romera, Jeane G. Francisco, Graziela C. R. Moura-Andrade \& Valdemar L. Tornisielo (2016) Relationship between antibiotic residues and occurrence of resistant bacteria in Nile tilapia (Oreochromisniloticus) cultured in cage-farm, Journal of Environmental Science and Health, Part B, 51:12, 817-823, DOI: 10.1080/03601234.2016.1208457

To link to this article: https://doi.org/10.1080/03601234.2016.1208457

\section{Published online: 05 Aug 2016.}

Submit your article to this journal ए]

Џlll Article views: 199

View Crossmark data \ulcorner

Citing articles: 5 View citing articles $匚$ 


\title{
Relationship between antibiotic residues and occurrence of resistant bacteria in Nile tilapia (Oreochromisniloticus) cultured in cage-farm
}

\author{
Sérgio H. Monteiro ${ }^{\mathrm{a}, \mathrm{b}}$, Fabiana Garcia ${ }^{\mathrm{c}}$, Kátia S. Gozi ${ }^{\mathrm{d}}$, Daiane M. Romera ${ }^{\mathrm{e}}$, Jeane G. Francisco ${ }^{\mathrm{b}}$, \\ Graziela C. R. Moura-Andrade ${ }^{\mathrm{b}}$, and Valdemar L. Tornisielo ${ }^{\mathrm{b}}$ \\ ${ }^{a}$ Biological Institute, São Paulo, SP Brazil; ${ }^{b}$ Center of Nuclear Energy on Agriculture, University of São Paulo, Piracicaba, SP, Brazil; ${ }^{~}$ Fisheries Institute, \\ Votuporanga, SP, Brazil; ${ }^{\mathrm{C} C e n t e r}$ of Aquaculture, São Paulo State University, Jaboticabal, SP, Brazil; ${ }^{\mathrm{e} A g r o n o m i c ~ I n s t i t u t e, ~ V o t u p o r a n g a, ~ S P, ~ B r a z i l ~}$
}

\begin{abstract}
The aim of this study was to investigate the relationship between antibiotic residues found in the muscle of cage-farm-raised Nile tilapia (Oreochromisniloticus), the occurrence of resistant bacteria, and the sanitary practices adopted by farmers in Ilha Solteira reservoir, Brazil. Nine fish (three small fish, 40-200 g; three medium-sized fish, 200-500 g; and three large fish, 500-800 g) were collected from four cage farms every three months from April 2013 to January 2014. Ten antibiotic residues were determined using liquid chromatography-mass spectrometry, and bacteria were isolated and tested for antibiotic resistance to determine the multiple antibiotic resistance (MAR) index. Only three antibiotics (oxytetracycline, tetracycline, and florfenicol) were detected in the muscle of Nile tilapia, and their residues were the highest in small fish; however, the MAR index was higher in large fish. In addition, a direct positive relationship between the MAR index and the concentration of antibiotic residues in Nile tilapia was found. Overall, the adoption of prophylactic management practices improved the sanitary status of cage farms, reducing bacterial infections and hampering the development of antibiotic-resistant bacteria.
\end{abstract}

ARTICLE HISTORY

Received 1 March 2016

KEYWORDS

Cage farming; MAR index; LC-MS/MS; reservoir; antibiotic resistance

\section{Introduction}

Tilapia production exceeded 3,500,000 t worldwide in 2011, showing an increasing trend; the top ten tilapia producers, including Brazil, supplied $88 \%$ of the global production. The Brazilian government has strongly encouraged cage farming in federal water bodies, resulting in the growth of tilapia production by $63 \%$ since $2010 .{ }^{[1]}$ The total area of reservoirs, lakes, and dams in Brazil is over 6.5 million ha, and water bodies are destined for multiple uses such as water supply, energy production, fish farming, recreation, navigation, and sand extraction. ${ }^{[2]}$ The expansion of aquaculture in artificial reservoirs is considered an important production alternative for populations affected by dam construction. ${ }^{[3]}$ However, planning, legislative compliance, and management and monitoring of the environmental quality of fish farms are required to minimize the impact of this expansion on aquatic environments. ${ }^{[4,5]}$

In Brazil, the use of intensive cage-farming systems has led to high fish population densities, crowding of farm sites, and lack of sanitary barriers, which increase the possibility of rapid infection spread and consequently make the use of antibiotics necessary. ${ }^{[6,7]}$ Antibiotic applications for preventing and controlling bacterial diseases in cage farms have not been monitored routinely, although they promote the development of antibiotic-resistant bacteria. ${ }^{[8]}$ The excessive use of antibiotics in animal rearing has the potential of backfiring and negatively affecting all the aspects of the industry, including its economic health. ${ }^{[9]}$ In addition, the horizontal gene transfer between antibiotic-resistant aquaculture bacteria and human pathogens might result in longer hospital stays and significantly higher medical costs for humans. ${ }^{[10]}$

Information on the biomonitoring of antibiotic residues in cage-farm raised Nile tilapia (Oreochromisniloticus) and the development of antibiotic-resistant bacteria is limited. ${ }^{[1]}$ Therefore, the objectives of the present study were to: (1) determine the levels of ten antibiotics in Nile tilapia collected from cage farms in Ilha Solteira reservoir, Brazil, and compare them against the maximum residue limits (MRLs) set by the European Union regulation, ${ }^{[12]}$ the Brazilian legislation, ${ }^{[13]}$ and the Codex Alimentarius; ${ }^{[14]}(2)$ assess the potential human health risks from fish consumption; (3) isolate and identify bacteria from Nile tilapia and determine the multiple antibiotic resistance (MAR) index; and (4) relate the antibiotic residues in the muscle of Nile tilapia to the occurrence of resistant bacteria and the sanitary practices adopted by farmers.

\section{Materials and methods}

\section{Study sites and sample collection}

The study was carried out at four cage farms of Nile tilapia located in Ilha Solteira reservoir, Paraná and Grande Rivers, Brazil. Each location was geo-referenced (https://www.google.com/maps/d/ viewer?mid=zEyzjaRFidFc.kK8v7rDFS31U\&msa $=0$ \&ll $=$ $-20.160387 \% 2 \mathrm{C}-50.975876 \& \mathrm{spn}=0.356451 \% 2 \mathrm{C} 0.676346)$ 
using an Aquaread AP 500 AgSolv sounder (Aquaread, Broadstairs, UK) equipped with a Global Positioning System. This probe was also used to assess the temperature and dissolved oxygen in the water. Fish farms were characterized using a questionnaire on annual production, mortality rate, the type, dose, and usage period of antibiotics, and prophylactic management practices. Nine Nile tilapia (three small fish, 40-200 g; three medium-sized fish, 200-500 g; and three large fish, 500$800 \mathrm{~g}$ ) were collected from each farm every three months from April 2013 to January 2014, except for Farm 2, which banned sample collection in the last two samplings. Preference was given to moribund fish, and collections were performed in the morning before the removal of dead fish. Fish were packed individually in plastic bags, stored in an ice chest, and transported to the laboratory.

\section{Determination of antibiotic residues in fish muscle}

In order to determine antibiotic residues, muscle samples with skin were removed, chopped, and crushed with dry ice using a blender. After proper labeling and conditioning in vials, crushed samples were stored at $-18^{\circ} \mathrm{C}$. Fish samples were prepared no later than $15 \mathrm{~d}$ post-collection as described by Monteiro et al. ${ }^{[15]}$ Briefly, the extraction was performed using $5 \mathrm{~g}$ of sample, $50 \mu \mathrm{L}$ of sulfadimethoxine-d6 (SDM-d6; $1.0 \mu \mathrm{g} \mathrm{mL}^{-1}$ ), $1 \mathrm{~mL}$ of $0.1 \mathrm{M}$ $\mathrm{Na}_{2}$ ethylenediaminetetraacetic acid, and $24 \mathrm{~mL}$ of acetonitrile water with $0.1 \%$ formic acid (70: $30, \mathrm{v} / \mathrm{v})$. The mixture was homogenized for 5 min using a Marconi MA102 ultraturrax (Piracicaba, SP, Brazil), and then centrifuged at $1,370 \times g$ for $5 \mathrm{~min}$. Next, $500 \mu \mathrm{L}$ of the supernatant was eluted in Captiva ND cartridge (Agilent Technologies, Santa Clara, CA, USA) using a Supelco Visiprep manifold (Sigma-Aldrich, St. Louis, MO, USA) and analyzed using liquid chromatography-mass spectrometry (LC-MS/MS; Agilent Technologies). Chromatographic separation was carried out using an Agilent Zorbax Eclipse Plus C18 $(3 \times 100 \mathrm{~mm} ; 3.5 \mu \mathrm{m})$ column. The mobile phase was Milli-Q water with $0.1 \%$ formic acid (A) and acetonitrile with $0.1 \%$ formic acid (B). The gradient program started at 5\% B with a linear gradient until $95 \%$ B in 13 min and then remained constant for $3 \mathrm{~min}$. After running for $15 \mathrm{~min}$, the re-equilibrium time (post time) was $10 \mathrm{~min}$ using $5 \% \mathrm{~B}$. The flow remained constant at $0.4 \mathrm{~mL} \mathrm{~min}^{-1}$, the column temperature was fixed at $30^{\circ} \mathrm{C}$, and the injection volume was $10 \mu \mathrm{L}$. Florfenicol was injected separately in a negative ionization mode. The chromatography conditions were the same, except for the gradient program that started at 30\% B for $2 \mathrm{~min}$, followed by a linear gradient until $95 \%$ B in $5 \mathrm{~min}$, and then remained constant for $2 \mathrm{~min}$. After running for $7 \mathrm{~min}$, the re-equilibrium time (post time) was 11 min using $30 \%$ B. A Triple Quadruple 6430 mass spectrometer (Agilent Technologies) was used as a detector. The antibiotic residues were identified using retention time and two multiple reaction monitoring (MRM) transitions.

Antibiotics were selected based on the Brazilian National Plan of Residues and Contaminants. ${ }^{[16]}$ The analytical standards of oxytetracycline ( $\geq 97 \%$; OTC), tetracycline ( $\geq 97.5 \%$; TC), chlortetracycline ( $\geq 93 \%$; CTC), ciprofloxacin ( $\geq 99.5 \%$; CFX), enrofloxacin ( $\geq 99 \%$; EFX), sarafloxacin ( $\geq 97.2 \%$; SAR), norfloxacin ( $\geq 99 \% ; \quad$ NFX), sulfathiazole ( $\geq 98 \%$; STZ), sulfadimethoxine-d6 ( $\geq 99.4 \%$; SDM-d6), and florfenicol ( $\geq 98 \%$; FF) were purchased from Sigma-Aldrich; sulfadimethoxine ( $\geq 99.5 \%$; SDM) and sulfamethazine ( $\geq 99.5 \%$; SMZ) were purchased from Chem Service (West Chester, PA, USA); and chloramphenicol ( $\geq 98.5 \%$; CAP) was purchased from Dr. Ehrestorfer GmbH (Augsburg, Germany).

The developed method was validated based on the Eurachem Guide. A matrix-matched calibration (MMC) was carried out with blank and spiked samples. The limits of detection ranged from 0.30 to $1.30 \mu \mathrm{g} \mathrm{kg}^{-1}$ and the limits of quantification range from 0.90 to $4.3 \mu \mathrm{g} \mathrm{kg}^{-1}$; the calibration curve showed linearity with correlation coefficient above 0.99 at the work range 5$400 \mu \mathrm{g} \mathrm{kg}^{-1}$, recovery ranged from $83.8 \%$ to $110.1 \%$. More details of procedure quality assurance, quality control procedures, and validation data, are available in Monteiro et al. ${ }^{[15]}$

\section{Risk assessment}

The risk assessment was evaluated by the estimated daily intake (EDI; ng d ${ }^{-1}$ person $^{-1}$ ), which was calculated for selected antibiotics via fish consumption by a specific age group of local people as follows: ${ }^{[17]}$

$$
E D I=\text { Cbiota } \times \text { Mbiota }
$$

Where Cbiota $\left(\mathrm{ngg}^{-1}\right)$ is the maximum concentration of selected antibiotics in adult biota samples (wet weight), and Mbiota $\left(\mathrm{g} \mathrm{d}^{-1}\right.$ person ${ }^{-1}$ ) is the daily consumption amount of selected fish by a specific age group. Daily fish consumption amounts were obtained from the Ministry of Fishing and Aquaculture, Brazil. ${ }^{[18]}$ The levels of antibiotics were compared with the MRLs set by the European Union regulation, the Brazilian legislation, and Codex Alimentarius. ${ }^{[14]}$

\section{Bacterial identification and antibiotic resistance}

Fish were weighted, and their body surface was disinfected with alcohol $\left(70^{\circ}\right.$ grade level) for $10 \mathrm{~min}$ under a laminar flow. Microbiological swab samples were collected aseptically from fish kidney and brain. Bacteria were identified by colony morphology, Gram staining, hemolysis on agar containing sheep blood $(5 \% \mathrm{v} / \mathrm{v})$, oxidase and catalase testing, and phenotypic profiling using API $20 \mathrm{E}$ and API 20 Strep Microbial Identification Strips (BioMerieux, Marcy L' Etoile, France) and molecular test by direct colony PCR using primers of $16 \mathrm{~S}$ rRNA gene. The identified bacteria were suspended in $0.85 \%$ saline solution and spread on Muller-Hinton agar Difco (MH) with 5\% sheep blood. ${ }^{[19]}$ Standard antibiotic disks of $10 \mu \mathrm{g}$ NFX, $5 \mu \mathrm{g}$ CFX, $5 \mu \mathrm{g}$ EFX, $25 \mu \mathrm{g} \mathrm{STZ}, 30 \mu \mathrm{g}$ CAP, $30 \mu \mathrm{g}$ FF, or $30 \mu \mathrm{g}$ tetracycline mix (OTC, TC, and CTC) were placed on the agar surface, and plates were incubated at $28^{\circ} \mathrm{C}$ for $18-24 \mathrm{~h}$. Next, the diameter of inhibition zones was measured, and bacteria were classified as resistant, intermediate, or susceptible to each antibiotic. The MAR index, which is the number of antibiotics to which the isolate was resistant divided by the number of antibiotics to which the isolate was exposed, was used to characterize each fish size and cage farm. ${ }^{[20]}$ 


\section{Statistical analysis}

Data normality was tested using the Shapiro-Wilk test. Analysis of variance (ANOVA) in conjunction with Tukey's test was used to identify significant differences at $P<0.05$. All analyses were performed using ASSISTAT (http://www.assistat.com/).

\section{Results}

\section{Characterization of cage farms}

The cage farms selected for this study exclusively raised Nile tilapia, and had an annual production of 120-1,800 $\mathrm{t}_{\text {year }}{ }^{-1}$. The number and size of cages differed between farms with a biomass of $60-70 \mathrm{~kg} \mathrm{~m}^{-3}$ in large cages $\left(108 \mathrm{~m}^{3}\right)$ and of $90-$ $100 \mathrm{~kg} \mathrm{~m}^{-3}$ in small cages $\left(6-18 \mathrm{~m}^{3}\right)$. Each farm followed a different management plan, but they all used salt and OTC and/or FF to prevent or control diseases (Table 1). Only one farm followed a specific prophylactic management plan, reduced fish density by $20 \%$ during the summer when water temperature reached $32^{\circ} \mathrm{C}$, and ran tests to identify any nutrient deficiencies (Farm 1; Table 1).

\section{Assessment of antibiotic residues in fish muscle}

A total of 126 Nile tilapia of three sizes were analyzed for antibiotic residues and the presence of antibiotic-resistant bacteria. The antibiotics detected in the muscle samples of Nile tilapia at concentrations above the limit of quantification were OTC, TC, and FF (Table 2). Small fish showed higher concentrations of antibiotic residues $(P<0.05)$ and a higher frequency of occurrence than medium and large fish. Antibiotic residues (OTC and FF) in large fish were detected in only two samplings throughout the study (Table 2). OTC was the most frequently detected molecule, found in $31 \%$ of the samples at a concentration of $10-1,379 \mu \mathrm{g} \mathrm{kg}^{-1}$, whereas TC was detected in samples with high OTC concentration. The highest total values of OTC and TC in small fish were above the MRLs set by the European Union regulation $\left(100 \mu \mathrm{g} \mathrm{kg}^{-1}\right)$ and the Brazilian legislation $\left(200 \mu \mathrm{g} \mathrm{kg}^{-1}\right)$. FF was mainly detected in small fish at a concentration over $300 \mu \mathrm{g} \mathrm{kg}^{-1}$,which was lower than the MRL recommended by the European Union regulation and the Brazilian legislation $\left(1,000 \mu \mathrm{g} \mathrm{kg}^{-1}\right)$. Both the EDI of OTC $\left(472 \mathrm{ng} \mathrm{day}^{-1}\right.$ person $\left.^{-1}\right)$ and FF (416 $\mathrm{ng} \mathrm{day}^{-1}$ person $^{-1}$ ) were below the acceptable daily intake determined by the Codex Alimentarius. $^{[14]}$

\section{Assessment of antibiotic resistance}

The bacterial genera identified were Pseudomonas, Burkholderia, Pasteurella, Streptococcus, and Aeromonas. Based on antibiotic resistance, the MAR index ranged from 0 to 0.86 , revealing the existence of bacteria susceptible to $100 \%$ of tested antibiotics and bacteria resistant to $86 \%$ of tested antibiotics (Table 3). Most bacteria were resistant to STZ, followed by TC, whereas the frequency of bacteria resistant to FF was the lowest (Table 3).

Table 1. Characterization of four Nile tilapia cage farms in Ilha Solteira reservoir, Brazil.

\begin{tabular}{|c|c|c|c|c|}
\hline \multirow[b]{2}{*}{ Characteristic } & \multicolumn{4}{|c|}{ Farm } \\
\hline & 1 & 2 & 3 & 4 \\
\hline Annual production $\left(\mathrm{t} \mathrm{yr}^{-1}\right)$ & 1,500 & 1,800 & 120 & 840 \\
\hline \multicolumn{5}{|l|}{ Number of cages } \\
\hline $2 \times 2\left(6 \mathrm{~m}^{3}\right)$ & - & - & 120 & - \\
\hline $3 \times 3\left(18 \mathrm{~m}^{3}\right)$ & 263 & 1,280 & 8 & 233 \\
\hline $6 \times 6\left(108 \mathrm{~m}^{3}\right)$ & 50 & 10 & - & - \\
\hline \multicolumn{5}{|l|}{ Biomass per cage $\left(\mathrm{kg} \mathrm{m}^{-3}\right)$} \\
\hline $2 \times 2\left(6 \mathrm{~m}^{3}\right)$ & - & - & 90 & - \\
\hline $3 \times 3\left(18 \mathrm{~m}^{3}\right)$ & 100 & 90 & - & 100 \\
\hline $6 \times 6\left(108 \mathrm{~m}^{3}\right)$ & 70 & 60 & - & - \\
\hline$\%$ of survivors & 90 & 70 & 80 & 90 \\
\hline \multicolumn{5}{|l|}{ Prophylactic methods } \\
\hline Quarantine & - & - & - & - \\
\hline Limnological monitoring & - & res & - & - \\
\hline Short bath salt ( $3-4 \%$ for $1 \mathrm{~min}$ ) during fish classification & res & res & res & - \\
\hline Long bath salt ( $5 \mathrm{~kg}$ bag of salt inside the cages) & - & - & - & - \\
\hline Oral antibiotic & - & - & - & - \\
\hline Antibiotic bath & $\begin{array}{c}\text { OTC in the classification and } \\
\text { initial stocking of fish }\end{array}$ & $\begin{array}{l}\text { OTC in the } \\
\text { classification }\end{array}$ & - & - \\
\hline Vaccination against Streptococcus agalactiae & Juvenile fish $30 \mathrm{~g}$ & - & - & Interrupted \\
\hline Reduction of stocking density in the summer & $-20 \%$ & - & - & $-5 \%$ \\
\hline Product to control Limnoperna fortune & Footoxi and Foothills & - & - & - \\
\hline Anesthetic during fish classification & Eugenol & - & - & Eugenol \\
\hline Commercial diet testing & - & - & - & res \\
\hline \multicolumn{5}{|l|}{ Therapeutic methods } \\
\hline Short bath salt (3-4\% for $1 \mathrm{~min})$ & - & - & - & $\begin{array}{c}\text { Potassium permanganate } \\
\text { to control monogenean } \\
\text { parasite }\end{array}$ \\
\hline Long bath salt ( $5 \mathrm{~kg}$ bag of salt inside the cages) & - & - & res & - \\
\hline Oral antibiotic & OTC and FF & OTC & OTC and FF & OTC and FF \\
\hline Temperature $\left({ }^{\circ} \mathrm{C}\right)$ & $24.4-30.4$ & $24.3-30.1$ & $24.7-30.5$ & $24.3-29.4$ \\
\hline Dissolved oxygen $\left(\mathrm{mg} \mathrm{L}^{-1}\right)$ & $4.62-6.90$ & $2.02-7.62$ & $3.5-8.86$ & $3.02-8.91$ \\
\hline
\end{tabular}

OTC, oxytetracycline; FF, florfenicol. 
Table 2. Concentration of antibiotic residues in Nile tilapia collected from April 2013 until January 2013 from four cage farms in Ilha Solteira reservoir, Brazil.

\begin{tabular}{|c|c|c|c|c|c|c|c|c|c|c|}
\hline \multirow[b]{2}{*}{ Farm } & \multirow[b]{2}{*}{ Fish size } & \multicolumn{2}{|c|}{ April 2013} & \multicolumn{2}{|c|}{ July 2013} & \multicolumn{2}{|c|}{ October 2013} & \multicolumn{3}{|c|}{ January 2014} \\
\hline & & OTC & $\mathrm{FF}$ & OTC & $\mathrm{TC}$ & OTC & $\mathrm{FF}$ & OTC & $\mathrm{TC}$ & $\mathrm{FF}$ \\
\hline & & \multicolumn{9}{|c|}{ Concentration $\left(\mu \mathrm{g} \mathrm{kg}^{-1}\right)$} \\
\hline \multirow[t]{3}{*}{1} & Small & $61.0( \pm 10.0) \mathrm{a}$ & - & $485.3( \pm 26.1)$ a & $11.0( \pm 0.3)$ & - & $416.9( \pm 26.9)$ a & - & - & $343.3( \pm 7.9)$ \\
\hline & Medium & $19.7( \pm 4.2) b$ & - & $32.5( \pm 0.9) b$ & - & - & - & - & - & - \\
\hline & Large & - & - & - & - & - & $10.4( \pm 2.2) b$ & - & - & - \\
\hline \multirow[t]{3}{*}{2} & Small & - & - & $10.9( \pm 0.8)$ & - & 0 & 0 & 0 & 0 & 0 \\
\hline & Medium & - & - & - & - & 0 & 0 & 0 & 0 & 0 \\
\hline & Large & - & - & - & - & 0 & 0 & 0 & 0 & 0 \\
\hline \multirow[t]{3}{*}{3} & Small & - & $524.7( \pm 3.5)$ & - & - & - & - & - & - & - \\
\hline & Medium & - & - & - & - & - & $26.6( \pm 9.0)$ & $90.1( \pm 24.9)$ & - & - \\
\hline & Large & - & - & - & - & - & - & - & - & - \\
\hline \multirow[t]{3}{*}{4} & Small & $1161.7( \pm 60.3)$ & - & $921.8( \pm 83.6)$ a & $12.0( \pm 0.7)$ & $724.9( \pm 59.5)$ a & - & $1298.7( \pm 69.7)$ & $32.4( \pm 5.4)$ & - \\
\hline & Medium & - & - & $13.0( \pm 1.4) b$ & - & $14.0( \pm 1.6) b$ & - & - & - & - \\
\hline & Large & - & - & $11.8( \pm 2.3) b$ & - & - & - & - & - & - \\
\hline
\end{tabular}

Data are presented as means \pm standard deviations. Means followed by the different letters within the same column are statistically different at $P<0.05$.

$\emptyset$ - Periods not sampled by decision of the fish farm owner.

OTC, oxytetracycline; FF, florfenicol; TC, tetracycline.

Farmers' answers revealed that antibiotics were used for juvenile fish, mainly during the classification management to prevent or control diseases, and were in agreement with the results of antibiotic residues in fish muscle. The highest concentrations of FF and OTC were found in small fish, whereas the
MAR index increased with fish size (Fig. 1). The MAR index of cage farms ranged from 0 to 0.23 (Fig. 2).

In Farm 1, we isolated only one bacterial species over the sampling period, and the MAR index was zero (Fig. 2). In the other three farms, the MAR index was directly related to the

Table 3. Frequency of resistant bacteria (\%) and the multiple antibiotic resistance (MAR) index of bacteria isolated from cage-farm raised Nile tilapia of three different sizes (small, medium, and large) in llha Solteira reservoir, Brazil.

\begin{tabular}{|c|c|c|c|c|c|c|c|c|c|c|c|}
\hline Date & Cage farm & Growth Phase & Strain & NFX & CFX & TC & EFX & STZ & CTC & $\mathrm{FF}$ & MAR \\
\hline \multirow{5}{*}{ April 2013} & \multirow[t]{2}{*}{2} & Large & Pseudomonas luteola & $\mathrm{S}$ & $\mathrm{s}$ & $\mathrm{S}$ & $\mathrm{s}$ & $\mathrm{s}$ & $\mathrm{s}$ & $\mathrm{S}$ & 0.00 \\
\hline & & Large & Aeromonashydrophila & $\mathrm{S}$ & $S$ & $\mathrm{~S}$ & $\mathrm{~s}$ & $\mathrm{~s}$ & $\mathrm{~s}$ & $\mathrm{~S}$ & 0.00 \\
\hline & \multirow{2}{*}{3} & Medium & Pasteurella sp. & $S$ & $S$ & $S$ & $S$ & $S$ & $S$ & $S$ & 0.00 \\
\hline & & Large & Pseudomonas aeruginosa & I & $\mathrm{s}$ & $\mathrm{s}$ & $\mathrm{S}$ & $\mathrm{S}$ & $\mathrm{s}$ & $\mathrm{s}$ & 0.14 \\
\hline & 4 & Small & Pseudomonas fluorescens & $\mathrm{S}$ & $\mathrm{s}$ & $\mathrm{S}$ & $\mathrm{s}$ & $\mathrm{R}$ & $\mathrm{s}$ & $\mathrm{s}$ & 0.29 \\
\hline \multirow{8}{*}{ July 2013} & 2 & Medium & Streptococcus agalactiae & $\mathrm{S}$ & $\mathrm{s}$ & $\mathrm{S}$ & $\mathrm{S}$ & $\mathrm{R}$ & $\mathrm{s}$ & $\mathrm{S}$ & 0.14 \\
\hline & \multirow[t]{4}{*}{3} & Small & Streptococcus agalactiae & $\mathrm{S}$ & $\mathrm{s}$ & $\mathrm{S}$ & $\mathrm{S}$ & $\mathrm{S}$ & $\mathrm{s}$ & $\mathrm{S}$ & 0.00 \\
\hline & & Small & Streptococcus agalactiae & $\mathrm{s}$ & $\mathrm{s}$ & $\mathrm{s}$ & $\mathrm{s}$ & $\mathrm{s}$ & $\mathrm{s}$ & $\mathrm{S}$ & 0.00 \\
\hline & & Medium & Streptococcus agalactiae & I & 1 & $\mathrm{~S}$ & I & $\mathrm{R}$ & $\mathrm{s}$ & $\mathrm{S}$ & 0.57 \\
\hline & & Large & Streptococcus agalactiae & $\mathrm{s}$ & $\mathrm{S}$ & $\mathrm{R}$ & $\mathrm{s}$ & $\mathrm{R}$ & $\mathrm{s}$ & $\mathrm{s}$ & 0.29 \\
\hline & \multirow[t]{3}{*}{4} & Small & Streptococcus agalactiae & $\mathrm{S}$ & $\mathrm{s}$ & $\mathrm{S}$ & $\mathrm{S}$ & $\mathrm{R}$ & $\mathrm{s}$ & $\mathrm{S}$ & 0.14 \\
\hline & & Small & Streptococcus agalactiae & $\mathrm{S}$ & $\mathrm{s}$ & $\mathrm{S}$ & $\mathrm{s}$ & $\mathrm{R}$ & $\mathrm{s}$ & $\mathrm{S}$ & 0.14 \\
\hline & & Large & Streptococcus agalactiae & $\mathrm{S}$ & $\mathrm{s}$ & $\mathrm{S}$ & $\mathrm{S}$ & $\mathrm{R}$ & $\mathrm{s}$ & $\mathrm{s}$ & 0.14 \\
\hline \multirow[t]{5}{*}{ October 2013} & \multirow[t]{5}{*}{3} & Medium & Streptococcus agalactiae & $\mathrm{s}$ & $\mathrm{s}$ & $\mathrm{s}$ & $\mathrm{s}$ & $\mathrm{s}$ & $\mathrm{s}$ & $\mathrm{S}$ & 0.00 \\
\hline & & Large & Streptococcus iniae & $\mathrm{S}$ & $\mathrm{s}$ & $\mathrm{S}$ & $\mathrm{S}$ & $\mathrm{s}$ & $\mathrm{s}$ & $\mathrm{S}$ & 0.00 \\
\hline & & Large & Streptococcus iniae & $\mathrm{s}$ & $\mathrm{s}$ & $\mathrm{s}$ & $\mathrm{s}$ & $\mathrm{s}$ & $\mathrm{s}$ & $\mathrm{s}$ & 0.00 \\
\hline & & Large & Aeromonashydrophila & I & $\mathrm{s}$ & $\mathrm{s}$ & $\mathrm{s}$ & $\mathrm{s}$ & 1 & $\mathrm{~S}$ & 0.29 \\
\hline & & Large & Streptococcus iniae & $\mathrm{R}$ & $\mathrm{R}$ & $\mathrm{R}$ & I & $S$ & I & I & 0.86 \\
\hline \multirow[t]{8}{*}{ January 2014} & \multirow[t]{8}{*}{4} & Small & Aeromonashydrophila & $\mathrm{s}$ & $\mathrm{s}$ & $\mathrm{s}$ & $\mathrm{S}$ & I & $\mathrm{s}$ & $\mathrm{S}$ & 0.14 \\
\hline & & Small & Aeromonashydrophila & $\mathrm{S}$ & $\mathrm{s}$ & $\mathrm{R}$ & $\mathrm{S}$ & $\mathrm{R}$ & $\mathrm{s}$ & $\mathrm{S}$ & 0.29 \\
\hline & & Small & Aeromonashydrophila & $\mathrm{S}$ & $\mathrm{s}$ & $\mathrm{S}$ & $\mathrm{s}$ & $\mathrm{R}$ & $\mathrm{s}$ & $\mathrm{S}$ & 0.14 \\
\hline & & Small & Serratialiquefaciens & $\mathrm{S}$ & $\mathrm{S}$ & $\mathrm{S}$ & $\mathrm{s}$ & $\mathrm{R}$ & $\mathrm{s}$ & $\mathrm{s}$ & 0.14 \\
\hline & & Small & Aeromonashydrophila & $\mathrm{S}$ & $\mathrm{s}$ & $\mathrm{R}$ & $\mathrm{s}$ & $\mathrm{R}$ & $\mathrm{s}$ & $\mathrm{s}$ & 0.29 \\
\hline & & Small & Aeromonascaviae & $\mathrm{S}$ & $\mathrm{s}$ & $\mathrm{S}$ & $\mathrm{S}$ & $\mathrm{R}$ & $\mathrm{S}$ & $\mathrm{S}$ & 0.14 \\
\hline & & Medium & Aeromonashydrophila & $\mathrm{s}$ & $\mathrm{s}$ & $\mathrm{S}$ & $\mathrm{s}$ & $\mathrm{R}$ & $\mathrm{s}$ & $\mathrm{s}$ & 0.14 \\
\hline & & Large & Aeromonashydrophila & $\mathrm{s}$ & $\mathrm{s}$ & $\mathrm{s}$ & $\mathrm{s}$ & $\mathrm{R}$ & $\mathrm{s}$ & $\mathrm{s}$ & 0.14 \\
\hline
\end{tabular}

Small, 40-200 g; Medium, 200-500 g; Large, 500-800 g.

$R$, resistant; I, intermediate; $S$, susceptible.

NFX, norfloxacin; CFX, ciprofloxacin; TC, tetracycline; EFX, enrofloxacin; STZ, sulfathiazole; CTC, chlortetracycline; FF, florfenicol. 


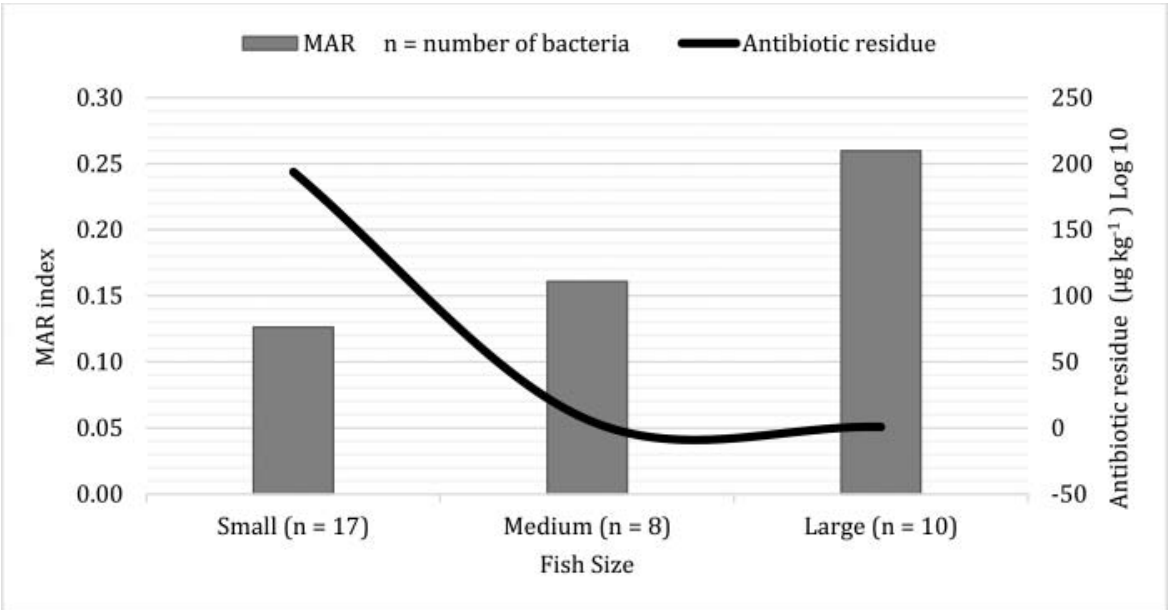

Figure 1. Relationship between the multiple antibiotic resistance (MAR) index of bacteria isolated from cage-farm raised Nile tilapia and the antibiotic residue concentration in small $(40-200 \mathrm{~g})$, medium $(200-500 \mathrm{~g})$, and large (500-800 g) fish.

concentration of antibiotic residues detected in Nile tilapia (Farms 2, 3, and 4; Fig. 2).

\section{Discussion}

In Ilha Solteira reservoir, $87.09 \%$ of the area is covered by pastures. ${ }^{[21]}$ Antibiotics have lower bioaccumulation and higher mobility potential in soil than pesticides. ${ }^{[22]}$ Although riparian vegetation functions as a buffer, filtering sediment nutrients and pollutants, ${ }^{[23]}$ only $0.67 \%$ of the natural vegetation surrounding Ilha Solteira reservoir prevents soil erosion. ${ }^{[21]}$ Therefore, antibiotics and contaminants present in the soil are easily carried to the reservoir.

In this study, the concentration of antibiotic residues was higher in small fish than in medium and large fish (Tables 1). According to farmers, small Nile tilapia is more susceptible to pathogens, and as a result, the use of antibiotics has intensified. However, the MAR index was higher in large fish, suggesting that the possibility of infection by bacteria resistant to multiple antibiotics increases with the time that fish stay in the aquatic environment. Little is known about the environmental impact of antibiotics used in aquaculture production and their accumulation in aquatic sediments. Previous studies showed that the bacterial flora in the environment surrounding aquaculture sites contains an increased number of antibiotic-resistant bacteria, ${ }^{[24-}$ ${ }^{27]}$ and that the aquatic environment is a great reservoir of antibiotic resistance genes. ${ }^{[28]}$ In Brazil, Nile tilapia are slaughtered when they reach a weight of $800 \mathrm{~g}$, and at this size, the detected concentrations of OTC and TC were below the MRLs. Although large fish intended for consumption show low antibiotic residues, the excessive use of antibiotics in industrial aquaculture has led to the consumption of undetected antibiotics that interfere with the normal bacterial flora of humans, increasing their susceptibility to bacterial infections, promoting the development of antibiotic-resistant bacteria, and generating allergy and toxicity problems. ${ }^{[29,30]}$ In Brazil, OTC and FF are the only licensed

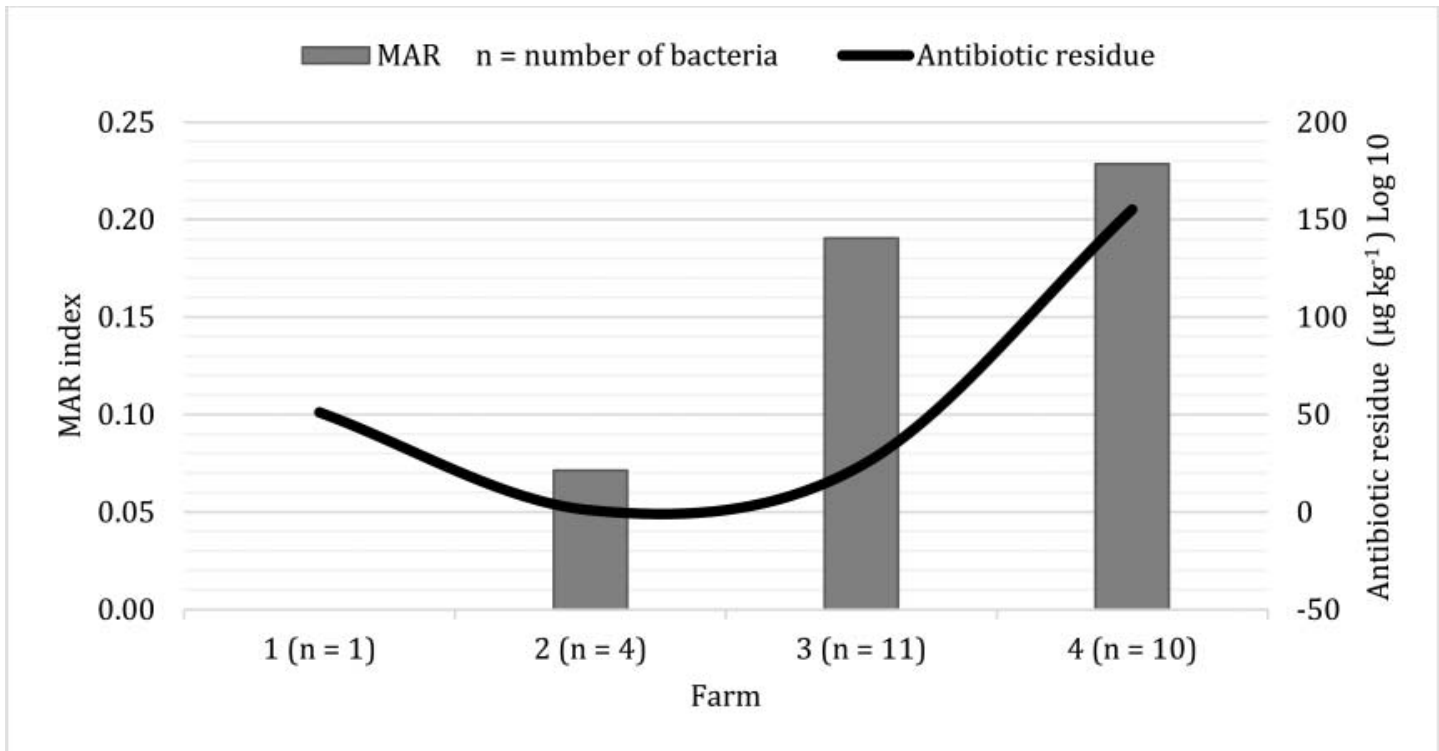

Figure 2. Relationship between the multiple antibiotic resistance (MAR) index of bacteria isolated from cage-farm raised Nile tilapia and the antibiotic residue concentration in each of four studied cage farms in llha Solteira reservoir, Brazil. 
antibiotics for use in the aquaculture production of crustaceans, tilapia, catfish, lobster, and salmon. ${ }^{[31]}$ The use of OTC is more popular because its commercial value is lower than that of FF. TC is one of the by-products of OTC, which is produced by fermentation of some strains of Streptomyces rimosus. ${ }^{[32]}$ In this study, the presence of TC could be attributed to the high OTC concentrations found in the samples. Thus, the presence of FF, TC, and OTC was directly related to the prevention or control of bacterial diseases in cage farms.

STZ showed the highest frequency of resistant bacteria (Table 3). This antibiotic is not used in Nile tilapia production, but it is one of the most prescribed systemic antibiotics in human and animal medicine. ${ }^{[28]}$ Therefore, the release of this antibiotic into the environment significantly promotes the development of resistant bacteria.

Owing to the continuous use of OTC as a prophylactic antibiotic, TC showed the second highest frequency of resistant bacteria (Table 3). The effectiveness of the fish immune system to fight bacterial colonization and infection is reduced with the increasing use of prophylactic antibiotics ${ }^{[6,7]}$ that often misplaces the goal of forestalling sanitary shortcomings. ${ }^{[33]}$ A previous study showed that OTC might not be the ideal antibiotic for aquaculture production because of its poor absorption from the intestinal tract of fish. ${ }^{[34]}$

FF showed the lowest frequency of resistant bacteria (Table 3), suggesting its efficacy as an antibiotic for the control of bacterial diseases in cage farms. FF is a broad-spectrum antibiotic that belongs to the amphenicol group, and is used in veterinary medicine. In several countries, it has been used as a community-acquired pneumonia substitute regimen and has shown high efficacy at low concentrations against pathogenic bacteria in fish, especially salmon and catfish. ${ }^{[35]}$

The results showed that the MAR index was directly related to the concentration of antibiotic residues detected in all cage farms, except for one (Farm 1), revealing that the continuous use of antibiotics could reduce their efficacy and promote the development of resistant bacteria. In addition, this study highlighted the importance of prophylactic management to prevent diseases, since, in Farm 1, only one bacterial species was isolated over the study, and the MAR index was 0 .

The Nile tilapia density in the cage farms of Brazil $\left(100 \mathrm{~kg} \mathrm{~m}^{-3}\right)$ is much higher than that of other countries $\left(2-50 \mathrm{~kg} \mathrm{~m}^{-3}\right)$. Therefore, when the water temperature reaches $32^{\circ} \mathrm{C}$ in the summer, a $20 \%$ reduction in fish density is considered an essential practice ${ }^{[4]}$ to reduce the risk of disease outbreaks, and consequently, decrease the mortality rate and increase the level of dissolved oxygen in the water. The relatively high dissolved oxygen level in Farm 1 reflected the positive consequence of this practice. Other prophylactic management practices, such as vaccination against $S$. agalactiae and commercial diet testing to identify possible nutrient deficiencies, also contribute to the improvement of the sanitary status in cage farms. Therefore, prophylactic management practices can reduce the use of antibiotics in aquaculture. ${ }^{[27,36]}$ Regulations in several developed countries specify the total elimination of antibiotic use for prophylaxis and the strict control of therapeutic antibiotics. ${ }^{[36]}$

\section{Conclusions}

Antibiotics detected in the muscle of Nile tilapia were OTC, TC, and $\mathrm{FF}$, and their presence was directly related to the control or prevention of bacterial diseases in cage farms. However, the EDI of FF and OTC was below the acceptable daily intake recommended by the Codex Alimentarius. ${ }^{[14]}$ The application of antibiotics in the cage farms of Brazil is intensified during the initial growth phase. This study showed that small fish had higher antibiotic concentrations, although the MAR index increased with the time that fish stayed in the aquatic environment. The comparison of cage farms revealed a direct relationship between the MAR index and the concentration of antibiotic residues in the muscle of Nile tilapia, suggesting that the continuous use of antibiotics can reduce their efficacy and promote the development of resistant bacteria. Overall, the adoption of prophylactic management practices, such as a $20 \%$ reduction in fish density during summer, vaccination against $S$. agalactiae, and commercial diet testing to identify possible nutrient deficiencies, is essential for improving the sanitary status of cage farms and reduce the MAR index.

\section{Funding}

This study was supported by FAPESP (Fundação de Amparo à Pesquisa do Estado de São Paulo) (Project 2011/18179-1).

\section{References}

[1] Food and Agriculture Organization of the United Nations. Fishery and aquaculture statistics; FAO: Rome, 2014. Available at http:// www.fao.org/3/a-i3740t/index.html (assessed Dec 2015).

[2] Rojas, A.; Wadsworth, S. A review of cage culture: Latin America and the Caribbean. In Cage Aquaculture-Regional Reviews and Global Overview; Halwart, M.; Soto, D.; Arthur, J.R., Eds.; FAO: Rome, 2007; 70-100.

[3] Abery, N.W.; Sukadi, F.; Budhiman, E.S.; Kartamihardja, E.S.; Koeshendrajana, S.; Buddhiman, S.; De Silva, S. Fisheries and cage culture of three reservoirs in west Java, Indonesia; a case study of ambitious development and resulting interactions. Fisheries Manag. Ecol. 2005, 12(5), 315-330.

[4] Garcia, F.; Romera, D.M.; Gozi, K.S.; Onaka, E.M.; Fonseca, F.S.; Schalch, S.H.C.; Candeira, P.G.; Guerra, L.O.M.; Carmo, F.J.; Carneiro, D.J.; Martins, M.I.E.G.; Portella, M.C. Stocking density of Nile tilapia in cages placed in a hydroelectric reservoir. Aquaculture. 2013, 410, 51-56.

[5] Neto, R.M.; Nocko, H.R.; Ostrensky, A. Environmental characterization and impacts of fish farming in the cascade reservoirs of the Paranapanema River, Brazil. Aquacul. Environ. Interact. 2015, 6(3), 255272.

[6] Naylor, R.; Burke, M. Aquaculture and ocean resources: Raising tigers of the sea. Annu. Rev. Environ. Resour. 2005, 30, 185-218.

[7] Naylor, R.N.; Goldburg, R.J.; Primavera, J.H.; Kautsky, N.; Beveridge, M.C.M.; Clay, J.; Folke, C.; Lubchenco, J.; Mooney, H.; Troell, M. Effect of aquaculture on world fish supplies. Nature. 2000, 405, 1017-1024.

[8] Aisyhah, M.A.S.; Amal, M.N.A.; Zamri-Saad, M.; Siti-Zahran, A.; Shaqinah, N.N. Streptococcus agalactiae isolates from cultured fishes in Malaysia manifesting low resistance pattern towards selected antibiotics. J. Fish Dis. 2015, 38(12), 1093-1098.

[9] Burridge, L.; Weis, J.S.; Cabello, F.; Pizarro, J.; Bostick, K. Chemical use in salmon aquaculture: A review of current practices and possible environmental effects. Aquaculture. 2010, 306(1-4), 7-23.

[10] World Health Organization. Antimicrobial Resistance: Global Report on Surveillance; WHO: Geneva, 2014. Available at http://apps.who. int/iris/bitstream/10665/112642/1/9789241564748_eng.pdf (assessed Jul 2015).

[11] Cabello, F.; Godfrey, H.P.; Tomova, A.; Ivanova, L.; Dolz, H.; Millano, A.; Buschmann, A.H. Antimicrobial use in aquaculture reexamined: its relevance to antimicrobial resistance and to animal and human health. Environ. Microbiol. 2013, 15(7), 1917-1942. 
[12] European Medicines Agency. Committee for Veterinary Medicinal Products; EMA: London, 2013. Available at http://www.ema.europa. eu/ema/index.jsp?curl=pages/medicines/landing/vet_mrl_search. jsp\&mid $=$ WC0b01ac058006488e (assessed Aug 2013).

[13] Geral, M.R. Plano nacional de Controle de Resíduos e Contaminantes; Ministério da Agricultura: Brasilia, 2009. Available at http://www. agricultura.gov.br/portal/page/portal/Internet-MAPA/pagina-inicial/ pncrc (assessed Dec 2015).

[14] Codex Alimentarius. Pesticide residues in food and feed; WHO: Geneva, 2012. Available at http://www.codexalimentarius.net/ pestres/data/pesticides/index.html (assessed Nov 2012).

[15] Monteiro, S.H.; Francisco, J.G.; Campion, T.F.; Pimpinato, R.F.; Moura Andrade G.C.R.; Garcia, F.; Tornisielo, V.L. Multiresidue antimicrobial determination in Nile tilapia (Oreochromisniloticus) cage farming by liquid chromatography tandem mass spectrometry. Aquaculture. 2015, 447, 37-43.

[16] Ministerio da Agricultura. InstruçãoNormativa $n^{\circ} 17$, de 29 Maio de 2013; Ministério da Agricultura: Brasilia, 2013. Available at http:// www.agricultura.gov.br/arq_editor/file/CRC/IN\%2017-2013(FINAL).pdf (assessed Dec 2015).

[17] United States Food and Drug Administration. Guidance for industry: estimating dietary intake of substances in food; FDA: Washington, DC, 2006. Available at http://www.fda.gov/Food/GuidanceRegula tion/GuidanceDocumentsRegulatoryInformation/IngredientsAdditi vesGRASPackaging/ucm074725.htm (assessed Dec 2015).

[18] Ministerio da Pesca e Aquicultura. Consumidores do Rio de Janeiro Aproveitam o Início da 11 $1^{\underline{a}}$ Semana do Peixe; MPA: Brasilia, 2014. Available at http://www.mpa.gov.br/ultimas-noticias/411-consumi dores-do-rio-de-janeiro-aproveitam-o-inicio-da-11-semana-dopeixe (assessed Sep 2015).

[19] Bauer, A.W.; Kirby, W.M.; Sherris, J.C.; Turck, M. Antibiotic susceptibility testing by a standardized single disk method. Am. J. Clin. Pathol. 1966, 45(4), 493-496.

[20] Krumperman, P. Multiple antibiotic resistance indexing of Escherichia coli to identify high-risk sources of fecal contamination of foods. Appl. Environ. Microbiol. 1983, 46(1), 165-170.

[21] Perreira, A.O. Caracterização do uso e ocupação do solo naárea de Influência do Reservatório de Ilha Solteira; Programa Recursos Hídricos e Tecnologias Ambientais, University of São Paulo State: São Paulo, 2006.

[22] Regitano, J.; Leal, R. Performance and environmental impact of antibiotics in animal production in Brazil. Rev. Bras. Cienc. Solo. 2010, 34(3), 601-616.

[23] Cavalcanti, G.; Lockaby, B.G. Effects of sediment deposition on aboveground net primary productivity, vegetation composition, and structure in riparian forests. Wetlands. 2006, 26(2), 400-409.
[24] Huys, G.; Rhodes, G.; McGann, P.; Denys, R.; Pickup, R.; Hiney, M.; Smith, P.; Swings, J. Characterization of oxytetracycline-resistant heterotrophic bacteria originating from hospital and freshwater fish farm environments in England and Ireland. Syst. Appl. Microbiol. 2000, 23(4), 599-606.

[25] Schmidt, A.S.; Bruun, M.S.; Daalsgaard, I.; Larsen, J.L. Incidence, distribution, and spread of tetracycline resistance determinants and integron-associated antibiotic resistance genes among motile aeromonads from a fish farming environment. Appl. Environ. Microbiol. 2001, 67(12), 5675-5682.

[26] Schmidt, A.S.; Bruun, M.S.; Daalsgaard, I.; Pedersen, K.; Larsen, J.L. Occurrence of antimicrobial resistance in fish-pathogenic and environmental bacteria associated with four Danish rainbow trout farms. Appl. Environ. Microbiol. 2000, 66(11), 4908-4915.

[27] Sørum, H. Antimicrobial drug resistance in fish pathogens. In Antimicrobial Resistance in Bacteria of Animal Origin; Aarestrup, F.M., Ed.; American Society of Microbiology Press: Washington, DC, 2006; 213-238.

[28] Caumo, K.; Duarte, M.; Cargnin, S.T.; Ribeiro, V.B.; Tasca, T.; Macedo, A.J. Resistênciabacteriana no meioambiente e implicaçõesnaclínicahospitalar. Rev. Liberato. 2010, 11(16), 89-188.

[29] Cabello, F.C. Antibiotics and aquaculture in Chile: Implications for human and animal health. Rev. Med. Chil. 2004, 132(8), 1001-1006.

[30] Salyers, A.A.; Gupta, A.; Wang, Y.P. Human intestinal bacteria as reservoirs for antibiotic resistance genes. Trends Microbiol. 2004, 12(9), 412-416.

[31] Sindan. Compêndio de Produtos Veterinários; CPVS: São Paulo, 2014. Available at http://www.cpvs.com.br/cpvs/ (assessed Feb 2014).

[32] Lykkeberg, A.K.; Halling-Sorensen, B.; Cornett, C.; Tjornelund, J.; Honore Hansen, S. Quantitative analysis of oxytetracycline and its impurities by LC-MS-MS. J. Pharm. Biomed. Anal. 2004, 34(2), 325332.

[33] Cabello, F.C. Heavy use of prophylactic antibiotics in aquaculture: a growing problem for human and animal health and for the environment. Environ. Microbiol. 2006, 8(7), 1137-1144.

[34] Bjorklund, H.V.; Rabergh, C.M.I.; Bylund, G. Residues of oxolinic acid and oxytetracycline in fish and sediments from fish farms. Aquaculture. 1991, 97(1), 85-96.

[35] Sadeghi, S.; Jahani, M. Selective solid-phase extraction using molecular imprinted polymer sorbent for the analysis of Florfenicol in food samples. Food Chem.2013, 141(2), 1242-1251.

[36] Lillehaug, A.; Lunestad, B.T.; Grave, K. Epidemiology of bacterial diseases in Norwegian aquaculture-a description based on antibiotic prescription data for the ten-year period 1991 to 2000. Dis. Aquat. Organ. 2003, 53(2), 115-125. 